\title{
学習院大学 上田玩哉
}

Self-acceptance as adaptively resigning the self to low self-evaluation

Takuya Ueda (Department of Psychology, Faculty of Letters, Gakushuin University, Mejiro, Toshima-ku, Tokyo 171)

In past studies, the concept of self-acceptance has often been confused with self-evaluation or self-esteem. The purpose of this study was to distinguish these concepts, and operationally define self-acceptance as Carl Rogers proposed: feeling all right toward the self when self-evaluation was low. Self-acceptance as adaptive resignation, a moderating variable, therefore should raise self-esteem of only those people with low self-evaluation. Selfacceptance was measuerd in the study as affirmative evaluation of own self-evaluation. Two hundred and forty college students, 120 each for men and women, completed a questionnaire of self-evaluative consciousness and self-esteem scales. Results of statistical analyses showed that among subjects with low self-evaluation, the higher self-acceptance, the higher the person's self-esteem. The same relation was not observed among those with high self-evaluation. Thus, it may be concluded that self-acceptance was adaptive resignation, and therefore meaningful to only those with low self-evaluation.

Key words: self-acceptance, self-evaluation, self esteem, adaptive resignation.

自己受容（self-acceptance）は，臨床心理学では特 に重要な概念の一つであり，多くの実証的研究も存在 するが，いまだにその定義に確立されたものを見な い. Crowne \& Stephens（1961）はこのことについて, 自己受容研究は現象学的には共通の出発点に立ってい るが, 定義が単一でないことはすべての研究者が認め るところであると言う。自己受容という概念が注目さ れ始めたのは, Rogers (1949) 以来である. Rogers （1949）は，心理療法の過程で, 治療が進むにつれて クライエントがしだいに自己に対する肯定的な意見を 示し，それに伴って他者に対しても肯定的な意見を示 すようになることを報告している。また Rogers （1961）は現実自己と理想自己との差異を適応の指標 として扱い,この差異が少ないほど自己受容的である と述べている。

自己受容と性格特性との関連についてもまた，いく つかの研究が進められてきた，自己受容と MMPI と の関係を論じたものに Berger（1952）があるが，それ

\footnotetext{
1 本論文は, 学習院大学文学部に 1994 年度卒業論文として提 出されたものに加筆・修正をしたものです.

本論文を執筆した後に田嶌（1991）の中に“健全なあきらめ” という表現が用いられているのを見つけました。ここに付記し てお断りします。

2 本論文の作成にあたり, 御指導頂きました学習院大学の永 田良昭教授，竹綱誠一郎助教授に深く感謝致します。
}

によると自己受容的な人は自分に自信をもつており， 無力感を感じず，防衛的な態度は弱いとされる．伊藤 （1992）は自己受容と YG 性格検査の各因子との間に ある程度の相関があるという報告をしている。しかし 研究者によって定義の仕方が異なっているにもかかわ らず，これらのことは共通する問題点を含んでいる。

従来の研究は自己受容と社会的な適応を並列的にと らえているものが多い（Bills, Vance, \& McLean, 1951)。そのため結果として，自己受容しているから 適応的なのか, 適応しているから自己受容的であるこ とができるのかが判然としない。自己受容は一般的に は“ありのままの自己を受け入れること”とされる が，“受け入れる”とは本来必ずしも肯定的であるこ とを意味しない. 従ってもともと自己受容とは自己に 対する肯定的態度を指すものではない。それは単に自 己の現実の姿を正確に観察し, 自分の特徵を十分自覚 していることを示すにすぎない。しかし Rogers （1961）が自己受容と考えた理想自己と現実自己の一 致度を測定する $\mathrm{Q}$ 分類法においても，その分類項目 は内容的には適応か不適応を表すものであり，そこで も自己受容度を測定するということは適応度を測定し ていることとほほ同義でしかないのである. Ogilive （1987）は，理想自己と現実自己の間の関係よりも， かくありたくない自己と現実自己との関係の方が，自 己満足度をよりょく予測すると言い, 現実自己と理想 
自己の差を問題にする理論は見直される必要があると 述べている．このように自己受容を適応的な人格や社 会的望ましさの側面からのみとらえるのでは不十分で あり, それは本研究で目指すものとも異なる。従っ て，ここでの目的を明らかにするため，以下に従来の 研究の問題点を整理する.

一つ目の問題点として挙げられるのは，自己受容 が，自己評価の高さと混同されることが多いというこ とである。もちろん自己に対する肯定的態度を表すと いう意味で自己受容と自己評価は類似した概念ではあ るが，外部の基準による価值判断を行うのか否かとい う点で両者は明確に異なる。自己受容が価值判断をま つたく含まないと言っているのではない。むしろ我及 はいかなる自分の特徵であっても，それを価值判断あ るいは評価することなしに認知することはないと言っ てよい. しかしその価値判断は外部の基準や他者との 比較によって行われるのではなく, 非常に主観的なも のである。従って自己受容は社会的望ましさのような 価值判断を超えた没価值的なものとしてとらえた方が 自然ではないだろうか.これに関連してCrowne \& Stephens（1961）は社会的望ましさの統制の失敗は, 結果がどうであろうと自己受容を解釈不能にしてしま うと述べている．例えば “人とうまく付き合っていく ことができる”と感じているということは，自己を高 く評価しているということであると同時に，当然社会 的な適応も示している。しかし逆にそう感じないとい うことは自己を低く評価していることを示してはいる が，そういう自分を受け入れているかいないかは別の 問題である. 従って自己受容的であることが適応的で あるとは必ずしも言えないのである。

二つ目の問題点は自己受容のもつメ夕認知的機能に ついてである. 従来の実証的な研究で問題となってい るのは，ある自己の特徴の有無（価值判断を含む） が, 直接に自己受容の程度として測定されている点に ある. しかし人間のさまざまな特徵を記述したものに 当てはまるかどうかでは結局自己評価的な意識までし か測り得ない. 自己受容が質問紙検査で程度として測 定しづらいのはここに原因があると考えられる。また 我妻（1964）のように，自己受容はインテンシヴな面 接を繰り返すことである程度とらえられるにしても， 質問紙検査ではとらえられないとする意見があるのも 事実である。Crowne \& Stephens（1961）は自己受容 の簡潔にして明瞭な定義の一つとして“自己評価にお ける満足の程度”という考え方を示したが，ここでわ ざわざ “自己評価における”と明言したのは，自己受 容が自己評価付するメ夕レベルの構えであることを 意識していたからではないだろうか。例えばふつう， 自分が引っ込み思案であったり，人付き合いが悪いと いうことを感じることは，すぐに自尊心の低下を引き 起こすであろう。この場合自己評価の低さと自尊心の
低下とは一義的に結び付いているのである。しかし自 己受容的な構えをもつ人は，そのような自分に対して も自尊心をもち続けられるのではないだろうか.なぜ なら，そこでは自分の劣等性の認識と劣等感とは明確 に区別されているからである、メタレベルで自らを肯 定している場合, 自己評価の低さが自尊心の低下と一 義的に結び付かないと予想できるのである。

今回の研究は, 以上のような問題点を検討し, 自己 受容の定義について再検討するものである。本研究で は, 先に挙げた二つの問題点を整理するために, 操作 的レベルでの狭義の自己受容として，“上手なあきら め”という考元方を提出する，それは自己評価の低い 人がそのことを認めた上で，“しょうがない”と感じ ることである。あるいはとういう自分でもよいと感じ ることである。これは自己評価の低い人に着目するこ とで, 適応の概念と比較でき, 自分の自己評価を認め た上でという点でメ夕認知的な構えであるということ が言えるものである。

Allport（1937 詫摩・青木・近藤・堀訳，1982） は, 成熟したパーソナリティには普遍的な三つの特徴 があるという.Allport（1937 詫摩他訳，1982）は その一つに自己客観化を挙げている。それはユーモア のセンスと微妙に結び付いており, 楽しみながら自分 を見つめる能力であるという。今回提案した “上手な あきらめ”で表現されるものは, Allport (1937 詫 摩他訳，1982）のこの考元と近く，それを更に操作的 に定義したものと言える.

本研究では, 自己受容的な人として自己評価は低い が，それでもなお自尊心の高い人を想定し，その人の 自己評価に対するメタレベルの肯定度を測定する。こ のメタレベル肯定度を自己評価の高い群と比較し，そ れが自尊心の向上にどの程度寄与しているかを明らか にすることを目的とする。また結果から自己受容の定 義に関する再検討を行う。仮説は以下のと扔りであ る。個人の自己評価とそれに対するメタレベルの肯定 度を測定したときに，そのメタレベル肯定度は，自己 評価の高群よりも低群にとって，より自尊心の向上に 作用しているであろう。つまりメタレベルの肯定度 は，自己評価の低い人にとってのみ“上手なあきら め”として, 自己受容的な構えの意味をもつであろ う.

\section{方法}

被検査者 都内私立大学の学生 240 名（男性 120 名, 女性 120 名).

調査時期 1994 年 7 月および 1995 年 7 月. 心理学 の講義の時間に配布し，後で回収した。

質問紙の構成 質問紙には教示と年齢，性別の質問 の後に以下の二つの尺度を設けている。 
1. 自己評価的意識尺度（梶田，1988）

自己評価的ニュアンスをもつ日常具体的な意識のあ り方を項目化したもので，30 項目からなる. 現在の 自分の状態が当てはまるかどうかを各項目に対し（は い・いいえ）の 2 件法で回答する。本研究では，ここ での目的にそって，梶田（1988）の尺度はそのままと して，自己評価に対するメタレベルの肯定度を測定す るために，各項目に（はい・いいえ）で回答させた後 に，そういう自分に対してどう感じるかを，5. 問題な くよいと思う一1. 非常によくないと思うまで 5 件法で 回答させるものを加えてある.

2. 自尊心尺度（Self-Esteem scale: Rosenberg, 1965)

全般的な自己概念の高さや自己満足の程度を測定す る 10 項目から構成される。今回は, 星野 (1970) に より日本語訳されたものを用いた。自尊感情の指標 は，1. 全く当てはまらない一-4. 非常に当てはまるまで の 4 件法とした.

\section{結果と考察}

\section{自己評価的意識の因子分析}

梶田（1988）の研究では, 自己評価的意識尺度の結 果を因子分析して, 自信・優越感・自己受容・自己防 衛性・自己への素直さの 5 因子を抽出している。また 男女間に因子の項目において顕著な違いが見られる。 しかし本研究では独自に再度因子分析（主因子法・バ リマックス回転）を行った。この理由は，梶田 （1988）の研究では自己受容という因子が存在し，こ れは自己受容を自己評価的意識と区別しようとする今 回の目的と矛盾するものだからである。また梶田 （1988）の研究では各因子の項目に男女間の違いが存 在したが, 本研究では男女別に因子分析した結果も, 男性の劣等性の因子と自己防衛の因子がまとまって表 現されたほかは一致していたため，男女を合計したも のを結果として用いた．因子別に区分した項目を Table 1 に示す. 本研究では, 梶田 (1988) の研究と は異なる五つの因子（自己評価・劣等性・自己嫌悪・ 自己防衛・優越性）を確認した。これらは梶田 （1988）の因子と類似した名称をつけたものもあるが, 項目の内容は異なっている。例えば, 梶田（1988）の 研究で, 青年男子の優越感の因子は, 本研究では優越 性の因子に該当すると思われる，その中で “尊敬され る人間になる”という項目などは共に同一因子に乗っ たが，“他の人をうらやましく思う”や“うわさが気 になる”といった項目は, 本研究ではむしろ劣等性の 因子に含まれた。この結果は特に不自然なものではな い.これは梶田（1988）の研究が実施されたものが 1972 年であったという, 本研究との年代的な差も関 係していると思われる。この中で自己評価の因子は
Table 1

自己評価的意識尺度の項目の分類

$\begin{array}{cl}\text { 第一因子 } & \text { 1.人とうまく付き合っていける } \\ \text { 自己評価 } & 10 . \text { 現在の自分に満足している } \\ & \text { 11.すべてわかってくれる友達がいる } \\ & \text { 13.人を信じることができる } \\ & \text { 14.自分の心を素直に表現できる }\end{array}$

15.自分に自信をもっている

16.人間は結局 1 人だと感じる

24.現在の自分は幸福だと思う

26.今度は別の人間に生まれ変わりたい

$\begin{array}{cl}\text { 第二因子 } & \text { 6.いつも人から好かれていたい } \\ \text { 劣等性 } & \text { 8.うわさが気になる } \\ & \text { 12.人からよく見られたい } \\ & \text { 21.他の人をうらやましく思う } \\ \text { 第三因子 } & \text { 2.失敗を自分のせいと思う } \\ \text { 自己嫌悪 } & 4 . \text { 自分の主張を通す } \\ & \text { 7.自分を頼りないと思う } \\ & \text { 18.自分自身がいやになる } \\ & 20 . \text { 自分を犠牲にできる } \\ & 23 . \text { くよくよと考えてしまう }\end{array}$

第四因子 17.ばかにされたりするのが我慢できない

自己防衛 27.自分が傷つくことを恐れている 28.今のままではいけないと思う 29.他人の反対が気になる

30.くやむことが多い

第五因子 19.他の人に比べて能力などが優れている

優越性２2.尊敬される人間になる

25.人に見られていると感じる

“人とうまく付き合っていける”“自分に自信をもって いる”など 9 項目を含む因子であり今後は自己評価的 意識の指標として, この因子を用いて論を進めていく こととする。

\section{相関による検定}

自尊心と自己評価・メタレベル肯定度との相関 ま ず自尊心と自己評価・メタレベル肯定度のそれぞれに ついて男女間で相関を比較した結果，女性の方が若干 相関係数が高かったが, 男女間に有意差は存在しなか った。男女を合わせた結果，自尊心と自己評価，また 自尊心とメタレベル肯定度との相関係数はそれぞれ $r=.53, r=.57$ であった. これら相関の有意性の検定 を行った結果，相関は有意なものであった（自尊心と 自己評価 $. t=9.75, d f=238, p<.01$, 自尊心とメタレ ベル肯定度 $. t=10.93, d f=238, p<.01)$ 。これからわ 
Table 2

自尊心とメタレベル肯定度の相関

\begin{tabular}{llcccc}
\hline & & 人数 & 分散 & 平均值 & メタレベル肯定度との相関 \\
\hline 自尊心得点 & 自己評価低群 $(0-4)$ & 128 & 20.28 & 24.34 & $r=.54$ \\
\cline { 2 - 6 } & 自己評価高群 $(5-9)$ & 112 & 15.01 & 28.35 & $r=.34$ \\
有意性検定の結果 & & & $F=1.82$ & $F=53.5$ & $\chi^{2}=3.73$ \\
& & & $p<.05$ & $p<.01$ & $p<.1$
\end{tabular}

Table 3

2 要因水準間の各組の自尊心得点の 平均值・標準偏差・標本数

〈メタレベル肯定度〉

低群 $(0.0-30.0)$ 高群 $(31.0-45.0)$

$\begin{array}{lrrr}\text { 自 } & \text { 低群 }(0-4) & 22.95 & 27.29 \\ \text { 己 } & 4.21 & 3.68 \\ \text { 評 } & \text { 高群 }(5-9) & 27.51 & 41 \\ \text { 価 } & 2.91 & 28.62 \\ & 27 & 4.13\end{array}$

上段：平均値

中段：標準偏差

下段 : 標本数

かるように自尊心との相関はそれぞれかなり高かっ た。もちろん自己を高く評価する人が，高い自尊心を もっているというのは当然予想されたことである。し かしメタレベル肯定度はそれ自体直接に自己受容度を 測定しているのではない，もしメタレベル肯定度が自 己評価の高低に関係なく，そのまま自己受容度を表し ているとすれば，自尊心との相関は自己評価よりも高 いことが推測される。しかし Hotellingの式による検 定の結果，これらの相関係数の間には有意な差は認め られなかった。つまりメタレベル肯定度の高さだけで 自己受容的であるとは言えないのである。これは仮説 とも合致する結果であり，自己評価との関連なく，メ タレベル肯定度を単独に測定しても，それだけでは自 己受容度を見ているとは言えず，自己受容が単純に程 度として測定しづらいことを示している。

自尊心とメタレベル肯定度との相関 次に自己評価 の高群，低群それぞれについて自尊心とメタレベル肯 定度の相関を見た（Table 2)。結果は自己評価高群の 相関と，低群の相関とも男女差がなかったため，男女 を込みにしたものである。自己評価の高低は全体の平 均值で分類した。ピヤスンの相関係数の同質性の検定 （岩原，1965）の結果，二つの相関の差は 5\%水準で
Table 4

自尊心の 2 元配置分散分析表

\begin{tabular}{lccc}
\hline 変動要因 & 自由度 & 平均平方和 & $F$ 值 \\
\hline 自己評価・高低 & 1 & 354.81 & $22.45^{* *}$ \\
メタレベル肯定度・高低 & 1 & 426.11 & $26.96^{* *}$ \\
交互作用 & 1 & 123.47 & $7.81^{* *}$ \\
$* * p<.01,{ }^{*} p<.05$ & & & \\
& & &
\end{tabular}

が認められた $\left(\chi^{2}=3.73\right)$.メタレベル肯定度は自己 評価の低群において自尊心との相関が高いのに比し て，自己評価高群でそれほど高い相関とはならなかっ た.これは仮説を完全に支持するとは言えないにして も，メタレベル肯定度が自己評価の低い人の自尊心に 深く関係していることを示す結果である.

\section{分散による検定}

まず自尊心の分散について男女間に差のないことを 確認した。自尊心の自己評価高群・低群の分散はそれ ぞれ Table 2 から 15.01 と 20.28 であった。二つの分 散の間に有意な差があるかどうかについての検定を行 った結果， $F=1.82$ となり，5\%水準で有意であった. この結果は本研究の仮説にとって傍証となる，自己評 価高群は分散があまり大きくなく，自尊心得点の高い 方に偏っている。一方自己評価低群の中には当然自尊 心の低い人も存在するが，そればかりでなくなかには 自尊心を高く維持している人も存在していることを示 す結果である。

\section{分散分析}

自己評価低群・高群それぞれについてメタレベル肯 定度によって，自尊心得点に有意な差があるかどうか を確かめるため, 性別×自己評価（高・低）×メタレ ベル肯定度（高・低）の 3 元配置の分散分析を行っ た。その結果，性別については主効果，交互作用とも に有意でなかったため, 男女を込みにして，自己評価 (高・低) $\times$ メレベル肯定度（高・低）の 2 元配置分 散分析を行った（Table 3, Table 4). Figure 1 にその 結果を図示した。結果から自己評価，メタレベル肯定 
度の主効果は共に有意であった $(p<.01)$.また $1 \%$ 水準で自己評価メメタレベル肯定度の交互作用が有意 であった. Figure 1 から, 交互作用について以下のこ とが言える。自己評価低群ではメタレベル肯定度の高 低によって自尊心得点に有意な差が存在した（ $p<$ .01）が，一方自己評価高群ではメタレベル肯定度は 自尊心得点に有意と認めることができるような影響を 及ぼしていない。つまりメタレベル肯定度は自己評価 の高低に影響を受け, 自尊心に与える意味合いが異な っていたのである.これは仮説を支持するものであ り, メタレベル肯定度が, 自己評価の高群には自尊心 を高く保つのに特別に作用していないが，自己評価の 低群には自尊心の向上に重要な役割を果たしているこ とを示している。つまり狭義の自己受容としての“上 手なあきらめ”の働きを，自己評価が低くてもな扔自 尊心の高い人のメタレベル肯定度の中に見出したので ある.ここで注意しなければならないのは, Figure 1 に見られるように, 自己評価低群の中で自己受容的と 言っても, その人の自尊心は, 平均的に見れば, 自己 評価高群の自尊心よりも低いのである. 逆に言えばこ れこそ“あきらめ”の本質であり, 尊大と言えるまで 自尊心が高くなることはないのである。これは Baumeister（1993）が指摘するように, 非常に低い自 尊心をもつ人が不適応的であるのと同様に, 非常に高 い自尊心をもつ人もまた不適応的であるという知見と 一致するものとしてとらえられることもできるであろ う.

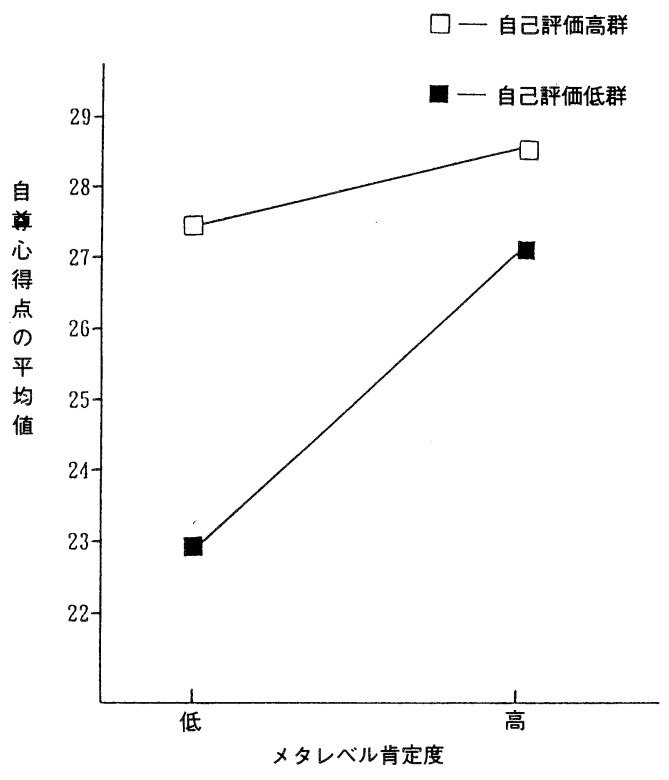

Figure 1. メタレベル肯定度と自尊心の関係.

\section{回帰の直線性の検定}

本研究では自己評価の低い人にとってメタレベル肯 定度の高さが自尊心の維持に影響しているという因果 関係を想定して論じてきたが，一方で自尊心の高さが 自己評価低群のメタレベル肯定度に影響しているとい う逆の因果関係も想定できる。これは簡単にはどちら が正しいかを決められない微妙な問題であるが, 推測 の手がかりとして，それぞれの回帰の直線性を検定し た. 具体的な分析方法は岩原（1965）を参考にして行 った.その結果，ともに5\%水準では有意とならず, 明らかに単回帰であると断言はできなかった。しかし $F$ 值に大きな差があり, 有意水準を $10 \%$ にとると, 二つの単回帰には差が見られた。つまり本研究で仮定 した自尊心の高さのメタレベル肯定度への回帰は有意 となり $(F=17.80, d f=1,2, p<.1)$, 逆にメタレベル 肯定度の高さの自尊心への回帰は有意とならなかった のである $(F=2.62, d f=1,2, n s)$.このことから, 少 なくとも今回の研究に関しては, 自尊心が高いから低 い自己評価に扮いてもそういう自分を良いと思えると いう因果関係よりも, 本研究で仮定した低い自己評価 を受け入れることによって自尊心を維持しているとい う因果関係の方がよりよく予測していると考えられ る.しかしあくまでこれは推測の手がかりであり, 詳 細な検討は今後の課題として残されるであろう.

これまでは仮説をさまざまな角度から検討してき た、結果から, 以下のように考察できる. Table 3, Table 4 で見られるように, 自己評価高群の方が, 当 然メタレベルの肯定度も全般的に高いが, それは自尊 心の高低にはあまり影響を及ぼしていない. 一方自己 評価低群は全体にメタレベル肯定度は低いものの, そ の働きが自尊心の高・低に強く影響していたのであ る.つまりメタレベル肯定度は, 自己評価の低い人に とってのみ媒介変数として自尊心の向上に意味をもっ てくるのである. 我々の多くは常に自己のネガティブ な側面と向かい合っている。そしてそういう自分と何 とか折り合いをつけていかなければならない。しかし 自己を高く評価している人, 社会的適応に優れている 人にとっては, 折り合いをつける必要度, 重要性は少 ない。つまり自己受容的な構えの働く余地がないので ある.メタレベルの肯定度が高いにもかかわらず，そ れが自尊心にほとんど影響を及ぼさなかったのはこの ためである、本研究のように自己評価の高い人が自己 受容的でなく,むしろ自己評価の低い人に自己受容的 な構えが存在するという, 一見逆説的に見える結果も 当然なのである。“受け入れる”とは自己が受け入れ られるものだからそう言えるのであり，受け入れがた い自分を受け入れる“あきらめ”にこそ自己受容的な 構えの意義があるのである. 最近は自己受容の適応的 な側面ばかり強調され, 安易にこの言葉が用いられる 
傾向がある．今回の研究で明らかになったように，自 己受容とは自己評価の高さや自尊心の高い状態と同じ とは単純に言い切れないものを含んでいるのであり， 今後の研究での更なる検討が望まれる。

\section{引用文献}

オールポート G. M. 詫摩武俊・青木孝悦・近藤由紀 子・堀 正(共訳) 1982 パーソナリティ 新曜社 (Allport, G. M. 1937 Personality. A psychological interpretation. Herry Holt Company.

Baumeister, R. F. 1993 Self-esteem: The puzzles of low self-regard. New York: Plenum Press.

Berger, E. M. 1952 The relation between expressed acceptance of self and expressed acceptance of others. Journal of Abnormal and Social Psychology, 47, 778-782.

Bills, R. E., Vance, E. L., \& McLean, O. S. 1951 An index of adjustment and values. Journal of Consulting Psychology, 15, 257-261.

Crowne, D. P., \& Stephens, M. W. 1961 Selfacceptance and self-evaluative behavior. A critique of methodology. Psychological Bulletin, 58, 104-121.
星野 命 1970 感情の心理と教育(二) 児童心理, 24, 1445-1477.

伊藤美奈子 1992 自己受容と性格特性との関連につ いての一考察 心理学研究, 63, 205-208.

岩原信九郎 1965 教育と心理のための推計学 日本 文化科学社

梶田嚄一 1988 自己意識の心理学 第2 版 東京大 学出版会

Ogilive, D. M. 1987 The undesired self: A neglected variable in personality research. Journal of Personality and Social Psychology, 52, 379-385.

Rogers, C. R. 1949 A coordinated research in psychotherapy. A nonobjective introduction. Journal of Consulting Psychology, 13, 149-153.

Rogers, C. R. 1961 On becoming a person. Boston: Houghton Mifflin.

Rosenberg, M. 1965 Society and adolescent self image. Princeton: Princeton University press.

田嶌誠一 1991 青年期境界例との“つきあい方” 心理臨床学研究, 9, 32-44.

我妻 洋 1964 自我の社会心理 誠信書房

-1995.8, 18 受稿, 1996.3.16 受理—— 